\title{
Nephropathy induced by contrast media: pathogenesis, risk factors and preventive strategies
}

\section{Ilan Goldenberg, Shlomi Matetzky}

\section{Abstract}

WITH THE INCREASING USE OF CONTRAST MEDIA in diagnostic and interventional procedures, nephropathy induced by contrast media has become the third leading cause of hospital-acquired acute renal failure. It is also associated with a significant risk of morbidity and death. The current understanding of the pathogenesis indicates that contrast-medium nephropathy is caused by a combination of renal ischemia and direct toxic effects on renal tubular cells. Patients with pre-existing renal insufficiency, diabetes mellitus and congestive heart failure are at highest risk. Risk factors also include the type and amount of contrast medium administered. Therapeutic prevention strategies are being extensively investigated, but there is still no definitive answer. In this article, we review the current evidence on the causes, pathogenesis and clinical course of contrast-medium nephropathy as well as therapeutic approaches to its prevention evaluated in clinical trials.

CMAJ 2005;172(11):1461-71

$\mathrm{N}$ ephropathy induced by contrast media is a significant yet underestimated problem in clinical practice. With the increasing use of contrast media in diagnostic and interventional procedures over the last 30 years, this form of nephropathy has become the third leading cause of hospital-acquired acute renal failure, accounting for $12 \%$ of all cases. ${ }^{1}$ The risk of contrast-medium nephropathy continues to be considerable, despite the use of newer and less nephrotoxic contrast agents in high-risk patients in recent years. ${ }^{2}$ Affected patients are at increased risk of morbidity and death. They may require short-term hemodialysis, which can extend their hospital stay and increase the risk of permanent impairment of renal function..$^{1-3}$ We review recent evidence on the incidence of and risk factors for contrast-medium nephropathy as well as the current understanding of its pathogenesis and the therapeutic approaches to its prevention that have been evaluated in clinical trials.

\section{Definition}

Contrast-medium nephropathy is usually defined as impairment of renal function occurring within 48 hours after administration of contrast media. ${ }^{4-6}$ It is manifested by an absolute increase in the serum creatinine level of at least $44 \mu \mathrm{mol} / \mathrm{L},,^{5,7-9}$ or by a relative increase of at least $25 \%$ over the baseline value ${ }^{10,11}$ in the absence of another cause. Because creatinine levels typically peak 3-5 days after administration of contrast media, ${ }^{1,3}$ this definition may overlook a large group of patients in whom nephropathy develops up to a week after administration of contrast media. However, older, more conservative definitions have a lower sensitivity because they require greater increases in the serum creatinine level. ${ }^{12,13}$ The current definition, which requires smaller increases in serum creatinine, is therefore more sensitive for the diagnosis of contrast-medium nephropathy associated with clinically important adverse short- and long-term outcomes. ${ }^{4,6,14}$

\section{Epidemiology and pathogenesis}

The rate of contrast-medium nephropathy reported in studies that included patients with pre-existing renal dysfunction or diabetes mellitus in whom a standard hydration protocol was not administered is between $12 \%$ and $26 \% .{ }^{4,7,15-18}$ Lower rates (3.3\%) have been reported among patients without these risk factors. ${ }^{5}$

Experimental studies suggest that contrast-medium nephropathy results from a combination of renal ischemia and direct toxic effects on renal tubular cells.

\section{Renal hemodynamic changes}

Early trials showed a transient increase in renal blood flow after injection of contrast medium that lasted up to 20 minutes followed by a more prolonged decrease in blood flow that lasted 20 minutes to hours. ${ }^{19,20}$ Subsequent animal studies showed that contrast media were associated with epithelial cell necrosis, primarily in the thin ascending limb in the renal medulla. The extent of these histologic changes correlated with the magnitude of disturbance in rat renal function. ${ }^{21}$

The renal medulla is uniquely susceptible to ischemic injury, and contrast media may cause medullar hypoxia by shunting blood flow to the renal cortex. ${ }^{22,23}$ It has been suggested that the development of contrast-medium nephropathy is affected by changes in renal hemodynamics because of the effects of the contrast medium on the action of many substances, including increased activity of renal vasoconstrictors (vasopressin, angiotensin II, dopamine-1, endothelin and adenosine) and decreased activity of renal vaso- 
dilators (nitric oxide and prostaglandins). ${ }^{24-26}$ Other factors that may decrease renal blood flow include increased viscosity of contrast media ${ }^{27}$ and increased erythrocyte aggregation induced by contrast media, which results in diminished oxygen delivery. ${ }^{28}$ Regardless of the underlying cause, animal studies have shown that the decreased renal blood flow and decreased glomerular filtration rate after exposure to contrast media seems to be more prominent among dehydrated rats than among animals with normal fluid volume. ${ }^{29}$

\section{Direct toxic effect on renal cells}

Pathological changes induced by contrast medium (e.g., epithelial cell vacuolization, interstitial inflammation and cellular necrosis) suggest a direct toxic effect of contrast media on renal tubular epithelial cells..$^{30,31}$ Apoptosis is also involved as a result of cellular injury. ${ }^{30}$ Contrast media have been found to reduce antioxidant enzyme activity in the rat kidney, and direct cytotoxic effects mediated by oxygen free radicals have been found in canine and rat models of contrast-medium nephropathy. ${ }^{30-33}$

\section{Effect of osmolality}

Experimental evidence has shown that hyperosmolar contrast media induce renal hemodynamic changes and have direct toxic effects on renal epithelial cells. Non-contrast hyperosmolar solutions, such as saline and mannitol, can cause renal vasoconstriction, which results in reductions in renal blood flow and the glomerular filtration rate, albeit of a lesser magnitude than reductions seen with contrast media. ${ }^{34,35}$ These nonspecific effects of hyperosmolality could be caused by osmolar-driven solute diuresis with activation of tubuloglomerular feedback or an increase in tubular hydrostatic pressures, which may cause compression of the intrarenal microcirculation and a decreased glomerular filtration rate. In addition, in an in vitro model with a renal epithelial cell line, DNA fragmentation (a marker of apoptosis) was increased in cells exposed to hyperosmolar contrast media, and the degree of fragmentation was proportional to the osmolality of the contrast medium. ${ }^{36}$ Thus, there is evidence of a direct cytotoxic effect of contrast media that is independent of hypoxia and may be related to hyperosmolality of the contrast agent. However, when the renal effects of isoosmolar contrast media, which have the lowest osmolality, were compared with the effects of hypo- and hyperosmolar contrast agents, there was no reduction in renal abnormalities with the iso-osmolar agents. ${ }^{37} \mathrm{~A}$ possible reason is the increased viscosity of the iso-osmolar agents. Iso-osmolar contrast media have been reported to cause more proximal tubular cell vacuolization, erythrocyte aggregation and cessation of blood flow in the renal microcirculation. ${ }^{38}$

Despite inconsistent results from experimental studies, clinical trials seem to show that hypo-osmolar contrast media are less nephrotoxic than hyperosmolar agents in high-risk patients. Pooled data from 25 randomized trials showed that the risk of contrast-mediuim nephropathy was greater with hyperosmolar contrast media than with hypoosmolar agents and that this difference was mostly limited to patients with pre-existing renal disease. ${ }^{39}$ Recently, it has been shown that iso-osmolar agents may be even less nephrotoxic than hypo-osmolar agents in such patients. ${ }^{40}$

\section{Risk factors}

Risk factors for contrast-medium nephropathy are related to patient characteristics and to the contrast medium used (Table 1). . $5,39,41,42^{-12}$

\section{Patient-related factors}

The most important patient-specific risk factors are preexisting renal insufficiency and diabetes (Table 1). The risk of contrast-medium nephropathy is directly proportional to the baseline serum creatinine level and increases further when diabetic nephropathy is present. ${ }^{43,44}$ Contrast-medium nephropathy developed in one-third of patients who underwent percutaneous coronary interventions and who had a baseline serum creatinine level of $177 \mu \mathrm{mol} / \mathrm{L}$ or greater. ${ }^{43}$ The incidence of contrast-medium nephropathy among diabetic patients has been reported to be $5 \%-30 \%$; ${ }^{42,44}$ even among these high-risk patients, clinically significant nephropathy usually occurred in patients with underlying renal dysfunction. ${ }^{5,44}$

A history of congestive heart failure is an independent risk factor for contrast-medium nephropathy and contributes an even greater risk in patients with diabetes or renal disease, ${ }^{5,42}$ probably because of the effect of low cardiac output on renal blood flow. Other predictors of con-

\section{Table 1: Risk factors for contrast-medium nephropathy}

\section{Risk factor}

Odds ratio $(95 \% \mathrm{Cl})$

\section{Patient-related}

Pre-existing renal dysfunction ${ }^{5}$

Serum creatinine level:

$1.2-1.9 \mathrm{mg} / \mathrm{dL}(106-176 \mu \mathrm{mol} / \mathrm{L})$

$2.0-2.9 \mathrm{mg} / \mathrm{dL}(177-264 \mu \mathrm{mol} / \mathrm{L})$

$\geq 3.0 \mathrm{mg} / \mathrm{dL}(265 \mu \mathrm{mol} / \mathrm{L})$

Diabetes mellitus ${ }^{4}$

Age $(1-y r \text { increment })^{5}$

Congestive heart failure

Hypertension $^{41}$

Low effective circulatory volume ${ }^{5}$

Myocardial infarction ${ }^{5}$

Use of intra-aortic balloon pump ${ }^{42}$

Other

Osmolality and content of contrast medium

in patients with pre-existing renal dysfunction

(low- v. high-osmolality) ${ }^{39}$

$1.12(1.02-1.23)$

Volume of contrast medium (per $100 \mathrm{~mL})^{5}$

$2.42(1.54-3.79)$

$7.37(4.78-11.39)$

$12.82(8.01-20.54)$

$5.47(1.40-21.32)$

$1.02(1.01-1.03)$

$1.53(1.21-2.10)$

$1.20(1.06-1.36)$

$1.19(0.72-1.95)$

$1.85(1.31-2.63)$

$1.94(1.08-3.49)$

Note: $\mathrm{Cl}$ = confidence interval. 
trast-medium nephropathy include the presence of hypertension ${ }^{41}$ increased age, acute myocardial infarction within 24 hours before administration of the contrast agent, ${ }^{5}$ hemodynamic instability and use of an intra-aortic balloon pump during percutaneous coronary intervention. ${ }^{5}$ Certain medications, including angiotensinconverting-enzyme (ACE) inhibitors and NSAIDs, have been implicated by their effects on regional renal hemodynamics. However, data on the risk of contrast-medium nephropathy associated with drug therapy are contradictory and have come mainly from animal studies and retrospective analyses. ${ }^{45,46}$

\section{Other factors}

Risk factors not related to the patient include the type and amount of contrast medium administered (Table 1). The use of hypo-osmolar or iso-osmolar contrast media has been found to be beneficial in reducing the incidence of contrast-medium nephropathy among high-risk patients but not among patients without risk factors. ${ }^{39,40} \mathrm{Ad}-$ ditional trials are needed to confirm that iso-osmolar contrast media are the least nephrotoxic in the clinical setting.

The volume of contrast medium administered correlates with the risk of nephropathy. ${ }^{4,5,47}$ In a series of consecutive patients undergoing coronary angiography, each $100 \mathrm{~mL}$ of contrast medium administered was associated with a significant increase of $12 \%$ in the risk of nephropathy. ${ }^{5}$ Adjustment of the volume to the patient's body weight and serum creatinine level has been found to minimize the risk. ${ }^{48}$ Similarly, it has been shown that exceeding a patient-specific maximum volume of contrast medium (recommended to be $5 \mathrm{~mL} \times$ [body weight (kilograms)/serum creatinine level (micromoles per litre) $\div 88.4]$ ) is associated with a 12 -fold increase in risk of hemodialysis. ${ }^{47}$ Therefore, the amount of contrast medium used should be kept to a minimum and not exceed patient-specific maximum doses.
Whether to use nonionic or ionic contrast agents is still inconclusive. In 2 large studies, the benefit of nonionic contrast media was limited to patients with pre-existing renal dysfunction, ${ }^{49,50}$ whereas a third study showed no benefit of nonionic over ionic contrast agents in patients either with or without preexisting renal dysfunction. ${ }^{51}$

\section{Risk stratification}

Mehran and colleagues ${ }^{52}$ developed a simple scoring method that integrates 8 baseline clinical variables to assess the risk of contrast-medium nephropathy after percutaneous coronary intervention (Box 1). They found that contrast-medium nephropathy was strongly associated with an increased risk score: the incidence was $7.5 \%$ among patients with a low score and $57.3 \%$ among those with a high risk score. This assessment tool uses readily available information and is easily incorporated into routine clinical practice in the evaluation of patients who might undergo procedures involving contrast media.

\section{Clinical presentation}

The serum creatinine level begins to rise within 24 hours after administration of a contrast medium in $80 \%$ of patients in whom contrast-medium nephropathy develops. In patients with severe renal failure necessitating a prolonged hospital stay or dialysis, the serum creatinine level almost always increases within the first 24 hours, ${ }^{53}$ typically peaking on the second or third day after administration of the contrast medium and returning to baseline values within 2 weeks. It has been shown that even transient rises in the serum creatinine level are associated with longer hospital stays. ${ }^{17}$

Although few patients with contrast-medium nephropathy require dialysis, these patients have poor short- and long-term survival (Table 2). ${ }^{4,42,54}$ About half require tempo-

\begin{tabular}{|c|c|c|c|c|}
\hline Study & $\begin{array}{l}\text { No. of } \\
\text { patients }\end{array}$ & Diagnostic procedure & $\begin{array}{c}\text { Dialysis } \\
\text { rate, \% }\end{array}$ & $\begin{array}{c}\text { Mortality after } \\
\text { dialysis, \% }\end{array}$ \\
\hline McCullough et $\mathrm{al}^{4}$ & 3695 & Coronary angiography & 0.5 & 37 \\
\hline Gruberg et $\mathrm{al}^{42}$ & 12054 & Coronary angiography & 0.4 & 17 \\
\hline Levy et $\mathrm{al}^{54}$ & 16248 & Radiocontrast procedure & 1.1 & 12 \\
\hline
\end{tabular}

Note: $\mathrm{CABG}=$ coronary artery bypass grafting. 
rary dialysis (<1 year), whereas the remainder require longterm dialysis. The rate of death among patients requiring temporary or long-term dialysis is high $(12 \%-37 \%)$.

\section{Prevention}

\section{Modification of risk factors}

When possible, the administration of contrast media should be delayed in patients with circulatory collapse or congestive heart failure until their hemodynamic status is corrected. Administration should be delayed for 24 hours after myocardial infarction. Repeated exposure should be delayed for 48 hours in patients without risk factors for contrastmedium nephropathy, and for 72 hours in those with diabetes mellitus or pre-existing renal dysfunction. If nephropathy develops, repeated exposure should be delayed until the patient's serum creatinine level has returned to baseline levels. ${ }^{2,12,53}$ NSAIDs, diuretics (when feasible) and possibly ACE inhibitors should be discontinued 1-2 days before administration of contrast media. ${ }^{53}$ Most importantly, the smallest possible amount of nonionic, hypo-osmolar or iso-osmolar contrast medium should be used in patients with risk factors.

\section{Therapeutic approaches evaluated in clinical trials}

\author{
Saline hydration and forced diuresis
}

A standardized saline hydration protocol has been proven effective in reducing the risk of contrast-medium nephropathy and should be used routinely (Table 3). ${ }^{7,55-58} \mathrm{In}$ a study of the effectiveness of saline, mannitol and furosemide in preventing contrast-medium nephropathy after cardiac angiography in patients with renal insufficiency, the incidence of nephropathy was significantly lower among patients who received saline alone $(11 \%)$ than among those who received saline plus mannitol $(28 \%)$ or saline plus furosemide (40\%). It was also considerably lower than the incidence reported among patients with similar pre-existing renal diseases who did not receive hydration in a standardized fashion. ${ }^{4,15-17}$ These results were confirmed by the Prevention of Radiocontrast Induced Nephropathy Clinical Evaluation (PRINCE) Study ${ }^{55}$ which found no benefit to forced diuresis with intravenous crystalloid, furosemide, mannitol or low-dose dopamine therapy over hydration alone in patients exposed to contrast media who were at risk for nephropathy. The lack of beneficial effects of

Table 3: Effectiveness of saline hydration or forced diuresis, or both, in preventing contrast-medium nephropathy reported in clinical trials

\begin{tabular}{|c|c|c|c|c|c|c|}
\hline Trial & $\begin{array}{c}\text { No. of } \\
\text { patients }\end{array}$ & $\begin{array}{l}\text { Baseline SCr level, } \\
\text { mean (SD), } \mu \mathrm{mol} / \mathrm{L}^{*}\end{array}$ & Intervention† & $\begin{array}{c}\text { Rate of } \\
\text { nephropathy, \% }\end{array}$ & $\begin{array}{l}\text { Superior } \\
\text { intervention }\end{array}$ & Comments \\
\hline Solomon et $\mathrm{al}^{7}$ & 78 & $186(53)$ & $\begin{array}{l}\text { - } 0.45 \% \text { saline } 12 \mathrm{~h} \text { before } \\
\text { and after contrast exposure } \\
\text { - } 25 \mathrm{~g} \text { of mannitol } 1 \mathrm{~h} \text { before } \\
\text { contrast exposure } \\
\text { - } 80 \mathrm{mg} \text { of furosemide } 30 \mathrm{~min} \\
\text { before contrast exposure }\end{array}$ & $\begin{array}{l}28 \\
40\end{array}$ & $\begin{array}{l}\text { Saline hydration } \\
\qquad(p=0.02)\end{array}$ & $\begin{array}{l}\text { Rate of nephropathy with saline } \\
\text { was lower than that previously } \\
\text { reported among other patients } \\
\text { with pre-existing renal disease } \\
\text { who did not receive a standard } \\
\text { hydration protocol }\end{array}$ \\
\hline \multirow[t]{2}{*}{ PRINCE $^{55}$} & \multirow[t]{2}{*}{98} & $\begin{array}{l}230(80) \\
203(71)\end{array}$ & $\begin{array}{l}\text { - } 0.45 \% \text { saline }(150 \mathrm{~mL} / \mathrm{h}) \\
\text { - Furosemide }(1 \mathrm{mg} / \mathrm{kg}) \\
+ \text { dopamine }(3 \mu \mathrm{gg} / \mathrm{kg} \text { per } \\
\text { min })+ \text { mannitol }(12.5 \mathrm{~g})\end{array}$ & $\begin{array}{l}31 \\
32\end{array}$ & \multirow[t]{2}{*}{ None } & \multirow[t]{2}{*}{$\begin{array}{l}\text { High urine flow rate was } \\
\text { associated with lower rate of } \\
\text { nephropathy (OR 0.91, } 95 \% \mathrm{Cl} \\
0.54-1.55)\end{array}$} \\
\hline & & $239(88)$ & - Furosemide + dopamine & 34 & & \\
\hline PREPARED $^{56}$ & 36 & $\geq 124$ & $\begin{array}{l}\text { - } 0.45 \% \text { saline }(75 \mathrm{~mL} / \mathrm{h}) \text { for } \\
12 \mathrm{~h} \text { before and after } \\
\text { contrast exposure } \\
\text { - Oral hydration }(1000 \mathrm{~mL} \\
\text { over } 10 \mathrm{~h}) \text { followed by } \\
0.45 \% \text { normal saline IV for } \\
6 \mathrm{~h} \text { before contrast exposure }\end{array}$ & $\begin{array}{l}\text { After } 48 \mathrm{~h}, \text { mean } \\
\text { SCr increased by } \\
0.21 \text { (SD } 0.38) \\
\text { After } 48 \mathrm{~h} \text {, mean } \\
\text { SCr increased by } \\
0.12(\text { SD } 0.23)\end{array}$ & None & $\begin{array}{l}\text { Larger quantities of fluids were } \\
\text { administered in the oral } \\
\text { hydration arm }\end{array}$ \\
\hline Mueller et $\mathrm{al}^{57}$ & 1620 & $\begin{array}{c}80 \\
\text { (range 44-141) }\end{array}$ & $\begin{array}{l}\text { - } 0.45 \% \text { sodium chloride } \\
\text { plus } 5 \% \text { glucose } \\
\text { - Isotonic }(0.9 \%) \text { saline }\end{array}$ & $\begin{array}{l}1 \\
2\end{array}$ & $\begin{array}{l}\text { Isotonic saline } \\
\quad(p=0.04)\end{array}$ & $\begin{array}{l}\text { Marked benefit was evident for } \\
\text { women, diabetic patients and } \\
\text { patients given > } 250 \mathrm{~mL} \text { of } \\
\text { contrast medium }\end{array}$ \\
\hline Merten et $\mathrm{al}^{58}$ & 119 & $\geq 97$ & $\begin{array}{l}\text { - Sodium chloride infusion } \\
\text { (154 mmol/L) } \\
\text { - Sodium bicarbonate infusion } \\
\text { (154 mmol/L) }\end{array}$ & 13.6 & $\begin{array}{l}\text { Sodium } \\
\text { bicarbonate } \\
(p=0.02)\end{array}$ & $\begin{array}{l}\text { A } 7 \text {-h hydration protocol } \\
\text { was used }(\mathrm{OR} 0.88,95 \% \mathrm{Cl} \\
0.79-0.97)\end{array}$ \\
\hline
\end{tabular}

Note: $\mathrm{SCr}=$ serum creatinine, $\mathrm{SD}=$ standard deviation, $\mathrm{NS}=$ not significant, $\mathrm{OR}=$ odds ratio, $\mathrm{Cl}=$ confidence interval.

*Unless stated otherwise.

†All interventions were intravenous (IV) unless stated otherwise.

fFor studies that did not report rates of contrast-medium nephropathy, the mean change in serum creatinine level $(\mu \mathrm{mol} / \mathrm{L})$ in each treatment group is given. 
mannitol and furosemide may be explained by their physiologic renal effects. Mannitol induces a process of active osmotic diuresis, which increases renal oxygen consumption and also acts as a potent renal vasoconstrictor. Furosemide-induced diuresis may result in hypovolemia, which may increase the risk of renal tubule injury induced by contrast media.?

Two recent prospective randomized studies evaluated different hydration protocols in patients undergoing procedures requiring contrast media (Table 3)..$^{57,58}$ The first study showed that the incidence of nephropathy was significantly lower among patients given an isotonic saline solution than among those given a hypotonic saline solution $(0.7 \% \mathrm{v}$. $2.0 \%$ respectively). ${ }^{57}$ In the second trial, hydration with sodium bicarbonate was found to be significantly more effective than hydration with sodium chloride in preventing contrast-medium nephropathy (incidence of nephropathy $1.7 \%$ v. $13.6 \%$ respectively). ${ }^{58}$ However, further studies are required to clarify the role of hydration with sodium bicarbonate in preventing such nephropathy.

\section{Vasodilators}

Fenoldopam: Fenoldopam mesylate is a selective dopamine-1 receptor agonist that produces systemic, peripheral and renal arterial vasodilatation. The drug exhibits many desirable renal effects that support its use for the prevention of contrast-medium nephropathy, including decreases in renal vascular resistance and increases in renal blood flow, glomerular filtration rate, and sodium and water excretion..$^{25}$ The benefit of fenoldopam for the prevention of contrast-medium nephropathy has been demonstrated in a dog model and in nonrandomized clinical studies. ${ }^{25,59-61}$ In a small double-blind, randomized controlled pilot trial, fenoldopam plus normal saline was found to attenuate reductions in renal blood flow induced by contrast media; it was also associated with a lower incidence of contrast-medium nephropathy than was normal saline alone, although the difference between the 2 groups was not significant. ${ }^{62}$ The benefit of fenoldopam was not validated in a large multicentre randomized placebo-controlled double-blind trial. ${ }^{63}$ Also, because of multiple confounders in the studies that did evaluate fenoldopam, a definitive conclusion regarding the drug's ability to protect against contrast-medium nephropathy could not be reached (Table 4).

In 2 recent large studies comparing fenoldopam with $\mathrm{N}$ acetylcysteine, treatment with fenoldopam either had a similar, nonsignificant effect as that of $\mathrm{N}$-acetylcysteine ${ }^{64}$ or was inferior to it. ${ }^{65}$ Therefore, the routine use of fenoldopam cannot be recommended at the present time.

Low-dose dopamine: Low-dose dopamine has been used to maintain renal perfusion and function in patients with renal insufficiency who have circulatory or hemodynamic instability. However, studies evaluating low-dose dopamine $(2-5 \mu \mathrm{g} / \mathrm{kg}$ per minute) for the prevention of contrast- medium nephropathy have shown conflicting results (Table 4). ${ }^{66-69}$ These different results may be related to the simultaneous activation of the dopamine receptor type $2\left(\mathrm{DA}_{2}\right)$, which, in contrast to the $\mathrm{DA}_{1}$ receptor, reduces renal blood flow and the glomerular filtration rate. ${ }^{70}$

Adenosine antagonists: Contrast media stimulate the intrarenal secretion of adenosine, which binds to the renal adenosine receptor and acts as a potent vasoconstrictor, reducing renal blood flow and increasing the generation of oxygen free radicals as it is metabolized to xanthine and hypoxanthine. Studies evaluating the adenosine antagonists (aminophylline and theophylline) have shown inconsistent results (Table 4), ${ }^{69,71-73}$ and therefore these antagonists should not be routinely used for the prevention of contrastmedium nephropathy.

Other vasodilator therapies with limited clinical evidence: The calcium-channel antagonists verapamil and diltiazem have been found to attenuate the renal vasoconstrictor response after exposure to radiocontrast media. ${ }^{74}$ However, when the efficacy of the dihydropyridine calcium-channel blockers felodipine, nitrendipine and nifedipine was evaluated, results were inconsistent. ${ }^{75,76}$

Endothelin-1, a potent endogenous vasoconstrictor, is thought to play a role in the development of contrastmedium nephropathy. However, the use of a mixed endothelin A and B antagonist (SB 290670) was associated with a significantly higher incidence of nephropathy than was placebo. $^{77}$

Prostaglandin $\mathrm{E}_{1}\left(\mathrm{PGE}_{1}\right)$ has vasodilatory effects that may be beneficial in preventing contrast-medium nephropathy. In one study, 130 patients were randomly assigned to receive either placebo or 1 of 3 doses of $\mathrm{PGE}_{1}$. All of the patients received $2 \mathrm{~L}$ of fluid before and after the contrast procedure. The increase in serum creatinine level was smaller in all of the $3 \mathrm{PGE}_{1}$ groups than in the placebo group, but the difference was significant only in the medium-dose $\mathrm{PGE}_{1}$ group $\left(20 \mathrm{ng} / \mathrm{kg}\right.$ per minute) ${ }^{78}$

\section{Antioxidants}

$\mathrm{N}$-acetylcysteine: This drug is inexpensive, well tolerated and devoid of significant side effects. It reduces renal damage by scavenging oxygen free radicals, generated as a result of toxic damage to renal tubules. ${ }^{8}$ In a randomized placebo-controlled clinical trial, $N$-acetylcysteine significantly reduced urinary levels of 15 -isoprostane $\mathrm{F} 2{ }_{\mathrm{t}}$, a specific marker of oxidative stress. ${ }^{79} \mathrm{~N}$-acetylcysteine may also have direct vasodilating effects on the kidneys through an increase in the biologic effects of nitric oxide, which is a potent and stable vasodilator contributing to improved renal hemodynamics. ${ }^{79}$ In one study, oral administration of $\mathrm{N}$-acetylcysteine plus standard saline hydration was compared with hydration alone in patients with chronic renal insufficiency (mean serum creatinine level 216 [standard deviation 116$] \mu \mathrm{mol} / \mathrm{L}$ ) undergoing coronary angiography with intravenous administration of $75 \mathrm{~mL}$ of a nonionic, 
Table 4: Effectiveness of vasodilators in preventing contrast-medium nephropathy reported in clinical trials

\begin{tabular}{|c|c|c|c|c|c|c|}
\hline Trial & $\begin{array}{l}\text { No. of } \\
\text { patients }\end{array}$ & $\begin{array}{l}\text { Baseline } \mathrm{SCr} \\
\text { level, mean } \\
\text { (SD), } \mu \mathrm{mol} / \mathrm{L}^{*}\end{array}$ & Intervention & $\begin{array}{c}\text { Rate of } \\
\text { nephropathy, \%† }\end{array}$ & $\begin{array}{l}\text { Superior } \\
\text { intervention }\end{array}$ & Comments \\
\hline \multicolumn{7}{|l|}{ Fenoldopam } \\
\hline Kini et $a^{60}$ & 110 & $>133$ & $\begin{array}{l}\text { - Fenoldopam mesylate } \\
(0.1 \mu \mathrm{g} / \mathrm{kg} \text { per } \mathrm{min}) \\
\text { - Historical controls }\end{array}$ & $\begin{array}{l}4.5 \\
19\end{array}$ & Fenoldopam & $\begin{array}{l}\text { Case-control series; coronary } \\
\text { interventions were associated with } \\
\text { hypotension }\end{array}$ \\
\hline Madyoon et al ${ }^{61}$ & 46 & $211(88)$ & $\begin{array}{l}\text { - Fenoldopam mesylate } \\
(0.1-0.5 \mu \mathrm{g} / \mathrm{kg} \text { per min) } \\
\text { - Conventional therapy }\end{array}$ & $\begin{array}{l}13 \\
38\end{array}$ & Fenoldopam & $\begin{array}{l}\text { Retrospective study; hydration not } \\
\text { specified }\end{array}$ \\
\hline Tumlin et $\mathrm{al}^{62}$ & 51 & $177-442$ & $\begin{array}{l}-0.45 \% \text { saline IV } \\
\text { - } 1 / 2 \text { normal saline }+ \\
\text { fenoldopam mesylate } \\
(0.1 \mu \mathrm{g} / \mathrm{kg} \text { per } \mathrm{min})\end{array}$ & $\begin{array}{l}41 \\
21\end{array}$ & None & $\begin{array}{l}\text { Dose and duration of fenoldopam } \\
\text { infusion may not have been } \\
\text { optimal; rate of nephropathy was } \\
\text { secondary end point }\end{array}$ \\
\hline CONTRAST ${ }^{63} \neq$ & 315 & $\begin{array}{l}\text { Cr clearance } \\
<60 \mathrm{~mL} / \mathrm{min}\end{array}$ & $\begin{array}{l}\text { - Saline + placebo } \\
\text { - } 1 / 2 \text { normal saline + } \\
\text { fenoldopam mesylate } \\
(0.1 \mu \mathrm{g} / \mathrm{kg} \text { per } \mathrm{min})\end{array}$ & $\begin{array}{l}30 \\
34\end{array}$ & None & $\begin{array}{l}\text { Dose and duration of fenoldopam } \\
\text { infusion may not have been } \\
\text { optimal; nonstandard hydration } \\
\text { protocol used }\end{array}$ \\
\hline \multicolumn{7}{|c|}{ Low-dose dopamine } \\
\hline Hans et $\mathrm{al}^{66}$ & 55 & 124-309 & $\begin{array}{l}\text { - Saline IV } \\
\text { - Saline IV + dopamine } \\
(2.5 \mu \mathrm{g} / \mathrm{kg})\end{array}$ & $\begin{array}{c}\text { After } 24 \mathrm{~h} \text {, mean } \\
\mathrm{SCr} \uparrow \text { by } \\
17.1 \mu \mathrm{mol} / \mathrm{L} \\
\text { After } 24 \mathrm{~h} \text {, mean } \\
\mathrm{SCr} \downarrow \text { by } \\
1.6 \mu \mathrm{mol} / \mathrm{L}\end{array}$ & None after $48 \mathrm{~h}$ & $\begin{array}{l}\text { Dopamine infusion showed } \\
\text { benefit after } 24 \mathrm{~h} \text { and in patients } \\
\text { whose baseline } \mathrm{SCr} \text { level was } \\
\geq 2 \mathrm{mg} / \mathrm{dL}(177 \mu \mathrm{mol} / \mathrm{L}) . \text { No } \\
\text { significant difference after } 48 \mathrm{~h}\end{array}$ \\
\hline Kapoor et al ${ }^{67}$ & 40 & $133(27)$ & $\begin{array}{l}\text { - Dopamine (2-5 } \mu \mathrm{g} / \mathrm{kg} \text { per min) } \\
\text { - Control group (no dopamine) }\end{array}$ & $\begin{array}{r}0 \\
50\end{array}$ & $\begin{array}{l}\text { Dopamine } \\
(p<0.05)\end{array}$ & \\
\hline Gare et $\mathrm{al}^{68}$ & 66 & $106 \quad(4)$ & $\begin{array}{l}\text { - } 0.45 \% \text { saline IV } \\
\text { - } 0.45 \% \text { saline IV + dopamine } \\
\text { ( } 5 \mu \mathrm{g} / \mathrm{kg} \text { per } \mathrm{min})\end{array}$ & $\begin{array}{l}\text { After } 48 \mathrm{~h} \text {, mean } \\
\mathrm{SCr} \uparrow \text { by } 11.5 \\
\text { (SD } 5.3 \text { ) } \mu \mathrm{mol} / \mathrm{L} \\
\text { After } 48 \mathrm{~h} \text {, mean } \\
\mathrm{SCr} \uparrow \text { by } 18.6 \\
\text { (SD 6.2) } \mu \mathrm{mol} / \mathrm{L}\end{array}$ & None & $\begin{array}{l}\text { Among patients with peripheral } \\
\text { vascular disease, change in } \mathrm{SCr} \\
\text { level was significantly greater in } \\
\text { dopamine group than in control } \\
\text { group }\end{array}$ \\
\hline $\begin{array}{l}\text { Abizaid et al }{ }^{69} \\
\text { (second phase } \\
\text { of study) }\end{array}$ & 72 & $230(44)$ & $\begin{array}{l}-0.45 \% \text { saline IV } \\
-0.45 \% \text { saline IV + dopamine } \\
\text { ( } 2.5 \mu \mathrm{g} / \mathrm{kg} \text { per } \min )\end{array}$ & $\begin{array}{l}30 \\
50\end{array}$ & $\begin{array}{l}\text { Trend toward } \\
\text { worse outcome } \\
\text { with dopamine } \\
(p=0.09)\end{array}$ & $\begin{array}{l}\text { Significantly more patients in } \\
\text { dopamine group than control } \\
\text { group required hemodialysis }\end{array}$ \\
\hline \multicolumn{7}{|c|}{ Aminophylline + theophylline } \\
\hline Kappor et $\mathrm{al}^{71}$ & 70 & $106(18)$ & $\begin{array}{l}\text { - } 0.9 \% \text { saline }(1 \mathrm{~mL} / \mathrm{kg} \text { per } \mathrm{h} \\
\text { (control) } \\
\text { - } 0.9 \% \text { saline }(1 \mathrm{~mL} / \mathrm{kg} \text { per } \mathrm{h}) \\
\text { + oral theophylline }(200 \mathrm{mg} \\
\text { twice daily) }\end{array}$ & $\begin{array}{l}20 \\
0\end{array}$ & $\begin{array}{l}\text { Oral } \\
\text { theophylline } \\
(p=0.017)\end{array}$ & $\begin{array}{l}>25 \% \text { decrease in GFR occurred } \\
\text { more frequently in control than in } \\
\text { theophylline group }(p=0.004)\end{array}$ \\
\hline Huber et $\mathrm{al}^{72}$ & 100 & $186(80)$ & $\begin{array}{l}\text { - } 0.45 \% \text { saline } \\
\text { - } 0.45 \% \text { saline + aminophylline } \\
\text { (200 mg IV) }\end{array}$ & $\begin{array}{r}4 \\
16\end{array}$ & $\begin{array}{l}\text { Aminophylline } \\
(p=0.046)\end{array}$ & \\
\hline $\begin{array}{l}\text { Abizaid et } \mathrm{al}^{69} \\
\text { (first phase of } \\
\text { study) }\end{array}$ & 60 & $168(35)$ & $\begin{array}{l}\text { - } 0.45 \% \text { normal saline } \\
\text { - Dopamine }(2.5 \mu \mathrm{g} / \mathrm{kg} \text { per min }) \\
\text { + saline hydration } \\
\text { - Aminophylline }(0.4 \mathrm{mg} / \mathrm{kg} \\
\text { per h) + saline hydration }\end{array}$ & $\begin{array}{l}30 \\
50 \\
35\end{array}$ & None & \\
\hline Erley et $\mathrm{al}^{73}$ & 80 & $168(44)$ & $\begin{array}{l}\text { - Theophylline orally ( } 270 \mathrm{mg} \\
\text { morning; } 540 \mathrm{mg} \text { evening) } \\
\text { - Placebo }\end{array}$ & $\begin{array}{l}6 \\
3\end{array}$ & None & \\
\hline
\end{tabular}

Note: $\mathrm{SCr}=$ serum creatinine, $\mathrm{SD}=$ standard deviation, $\mathrm{GFR}=$ glomerular filtration rate.

*Unless stated otherwise

†For studies that did not report rates of contrast-medium nephropathy, the mean change in serum creatinine level $(\mu$ mol/L) in each treatment group is given.

‡Odds ratio (95\% confidence interval): 1.11 (0.79-1.57). Odds ratios for other studies were not reported. 
hypo-osmolar contrast agent. ${ }^{8}$ The incidence of contrastmedium nephropathy was significantly lower in the $\mathrm{N}$ acetylcysteine group than in the control group. However, the results of this study are confounded by a higher than expected incidence of contrast-medium nephropathy in the control group (21\%). This rate is considerably higher than the rate of $11 \%$ among patients receiving saline hydration alone in a study reported by Solomon and associates, ${ }^{7}$ despite the fact that the latter study frequently used hyperosmolar, ionic contrast media and higher volumes of contrast agents. Subsequent trials of $\mathrm{N}$-acetylcysteine in patients with chronic renal insufficiency have provided conflicting results. ${ }^{9,6480,81}$ A meta-analysis of the first 7 reported trials showed that, compared with peri-procedural hydration alone, administration of $N$-acetylcysteine plus hydration reduced the risk of contrast-medium nephropathy by $56 \%$ among patients with chronic renal insufficiency (odds ratio $0.44,95 \%$ confidence interval 0.22 $0.88, p=0.02) .^{82}$ The authors of 2 other meta-analyses ${ }^{83,84}$ stated that it was impossible to draw general conclusions about the benefit of $\mathrm{N}$-acetylcysteine in preventing contrast-medium nephropathy because of inconsistent study designs of the analyzed trials. A systematic review showed that studies reporting negative results for $\mathrm{N}$-acetylcysteine had enrolled patients at lower overall risk of contrastmedium nephropathy compared with studies reporting positive results (incidence of nephropathy $11 \%$ and $24.8 \%$ respectively). ${ }^{85}$ Therefore, $\mathrm{N}$-acetylcysteine may be of benefit mostly in high-risk patients. We performed a metaanalysis that showed an overall benefit of the drug, but only in patients with more severe renal dysfunction (serum creatinine level $>221 \mu \mathrm{mol} / \mathrm{L}$ ) or when a nonstandard or incomplete hydration protocol was used ${ }^{86}$ (Table 5). By contrast, in trials showing no effect of $N$-acetylcysteine, patients had had less severe renal insufficiency and a uniform 24-hour hydration protocol had been used (Table 6). In patients undergoing emergency diagnostic procedures, in whom a full hydration protocol is not possible, an abbreviated hydration regimen plus oral ${ }^{90}$ or intravenous ${ }^{91}$ administration of $\mathrm{N}$-acetylcysteine was successful in reducing the rate of contrast-medium nephropathy.

The development of contrast-medium nephropathy seems to depend on the amount of contrast agent given and on the dose of $N$-acetylcysteine. ${ }^{92}$ In one study $N$-acetylcysteine prevented nephropathy in patients receiving small amounts of contrast medium, ${ }^{11}$ whereas in another it was efficient in patients receiving moderate to high volumes ${ }^{80}$ In another study, a double dose of $\mathrm{N}$-acetylcysteine plus intravenous saline hydration administered before and after angiography in patients with chronic renal insufficiency significantly reduced the incidence of contrast-medium nephropathy compared with a single dose of $N$-acetylcysteine. ${ }^{92}$

Table 5: Summary of prospective studies of $N$-acetylcysteine (NAC) versus placebo for the prevention of contrast-medium nephropathy in patients undergoing elective diagnostic procedures in which a beneficial effect was shown

\begin{tabular}{|c|c|c|c|c|c|c|c|}
\hline Study & $\begin{array}{c}\text { No. of } \\
\text { patients }\end{array}$ & NAC dose & Procedure & $\begin{array}{l}\text { Baseline SCr level, } \\
\text { mean (SD), } \mu \mathrm{mol} / \mathrm{L}\end{array}$ & $\begin{array}{l}\text { Increase in } \mathrm{SCr} \\
\text { level used to define } \\
\text { nephropathy }\end{array}$ & $\begin{array}{c}\text { Rate of } \\
\text { nephropathy, \% }\end{array}$ & $\begin{array}{l}\text { Odds ratio } \\
(95 \% \mathrm{Cl})^{*}\end{array}$ \\
\hline $\begin{array}{l}\text { Diaz-Sandoval } \\
\text { et } \mathrm{al}^{10}\end{array}$ & 54 & $\begin{array}{l}600 \mathrm{mg} \text { twice } \\
\text { daily ( } 1 \text { dose } \\
\text { before and } 3 \\
\text { doses after the } \\
\text { procedure) } \dagger\end{array}$ & $\begin{array}{l}\text { Coronary } \\
\text { angiography }\end{array}$ & $141 \quad(4)$ & $>25 \%$ & $\begin{array}{l}\text { NAC: } 8 \\
\text { Placebo: } 45 \% \\
p=0.005\end{array}$ & $0.21(0.06-0.80)$ \\
\hline Kay et $\mathrm{al}^{87}$ & 200 & $\begin{array}{l}600 \mathrm{mg} \text { twice } \\
\text { daily for } 48 \mathrm{~h} \dagger\end{array}$ & $\begin{array}{l}\text { Coronary } \\
\text { angiography } \\
\text { with or without } \\
\text { angioplasty }\end{array}$ & 124 & $>25 \%$ & $\begin{array}{l}\text { NAC: } 4 \\
\text { Placebo: } 12 \\
p=0.03\end{array}$ & $0.32(0.10-0.96)$ \\
\hline Shyu et $\mathrm{al}^{9}$ & 121 & $\begin{array}{l}400 \mathrm{mg} \text { twice } \\
\text { daily for } 48 \mathrm{~h}\end{array}$ & $\begin{array}{l}\text { Coronary } \\
\text { angioplasty }\end{array}$ & $248 \quad(71)$ & $\geq 44 \mu \mathrm{mol} / \mathrm{L}$ & $\begin{array}{l}\text { NAC: } 3 \\
\text { Placebo: } 25 \\
p<0.001\end{array}$ & $0.13(0.08-0.20)$ \\
\hline Tepel et $\mathrm{al}^{8}$ & 83 & $\begin{array}{l}600 \mathrm{mg} \text { twice } \\
\text { daily for } 48 \mathrm{~h}\end{array}$ & $\begin{array}{l}\text { Diagnostic CT } \\
\text { scanning }\end{array}$ & $216(116)$ & $\geq 44 \mu \mathrm{mol} / \mathrm{L}$ & $\begin{array}{l}\text { NAC: } 2 \\
\text { Placebo: } 21 \\
p=0.01\end{array}$ & $0.10(0.02-0.90)$ \\
\hline Miner et $\mathrm{al}^{81}$ & 180 & $\begin{array}{l}2000 \text { mg twice } \\
\text { daily (total 2-3 } \\
\text { doses) }\end{array}$ & $\begin{array}{l}\text { Coronary } \\
\text { angiography } \\
\text { or angioplasty }\end{array}$ & 132 & $\geq 25 \%$ & $\begin{array}{l}\text { NAC: } 10 \\
\text { Placebo: } 22 \\
p=0.04\end{array}$ & $0.37(0.14-0.93)$ \\
\hline MacNeill et al ${ }^{88}$ & 43 & $\begin{array}{l}600 \mathrm{mg} \text { twice } \\
\text { daily for } 48 \mathrm{~h} \dagger\end{array}$ & $\begin{array}{l}\text { Coronary } \\
\text { angiography }\end{array}$ & 141 & $\geq 25 \%$ & $\begin{array}{l}\text { NAC: } 5 \\
\text { Placebo: } 32 \\
p=0.046\end{array}$ & $0.11(0.01-0.99)$ \\
\hline
\end{tabular}

Note: $\mathrm{SCr}=$ serum creatinine, $\mathrm{SD}=$ standard deviation, $\mathrm{Cl}=$ confidence interval

${ }^{*}$ Odds ratios are for NAC $v$. placebo with end point of contrast-medium nephropathy.

†24-hour hydration protocol not used. 
Given the mixed results of $N$-acetylcysteine studies and the lack of evidence-based consensus, only a general recommendation for the use of the drug can be made at this time. It may be used to prevent contrast-medium nephropathy in high-risk patients and as an abbreviated oral or intravenous regimen in patients requiring emergency diagnostic procedures using contrast media. The role of acetylcysteine as an adjunct to full saline hydration in lower-risk patients with mild renal insufficiency appears to be more limited.

Ascorbic acid: A recent randomized trial showed that the use of ascorbic acid was associated with a significant reduction of $62 \%$ in the rate of contrast-medium nephropathy among patients with renal insufficiency undergoing coronary angiography with or without intervention..$^{33}$ Further prospective studies are needed to validate these preliminary results.

\section{Hemofiltration and hemodialysis}

Hemodialysis immediately after exposure to contrast media has not been shown to be effective in preventiing nephropathy in patients with pre-existing renal insufficiency, and it may even increase the risk of nephropathy. ${ }^{94}$ In a higher-risk patient population (mean serum creatinine level $265 \mu \mathrm{mol} / \mathrm{L}$ ), hemofiltration seems to have a protective effect, including significant reduction in in-hospital and 1-year mortality compared with routine hydration. ${ }^{95}$ However, the expense and complexity of hemodialysis may prevent its general application in procedures that require the use of contrast media.

\section{Conclusions and future directions}

The increasing number of diagnostic and therapeutic procedures that require the use of contrast media makes the prevention of contrast-medium nephropathy an important goal. Unfortunately, no single pharmacologic compound has been found yet that consistently improves on results seen with hydration alone.

There are general guidelines for the management of patients undergoing procedures requiring contrast agents (Fig. 1) and for risk assessment of contrast-medium nephropathy (Table 1, Box 1). In high-risk patients, the total dose of the contrast agent should be kept to a minimum, and hypo-osmolar or iso-osmolar agents should be used. In addition, all patients should receive adequate hydration. The benefit of pharmacologic prevention appears to be limited. $N$-acetylcysteine may be used in high-risk patients and in patients in whom full saline hydration cannot be administered. Under special circumstances, when a diagnostic procedure requiring contrast media has to be used in very high-risk patients (patients in intensive care

Table 6: Summary of prospective studies of $N$-acetylcysteine (NAC) versus placebo for the prevention of contrast-medium nephropathy in patients undergoing elective diagnostic procedures in which a beneficial effect was not shown*

\begin{tabular}{|c|c|c|c|c|c|c|c|}
\hline Study & $\begin{array}{l}\text { No. of } \\
\text { patients }\end{array}$ & NAC dose & Procedure & $\begin{array}{c}\text { Baseline } \\
\text { SCr level, mean } \\
(\mathrm{SD}), \mu \mathrm{mol} / \mathrm{L}\end{array}$ & $\begin{array}{l}\text { Increase in } \mathrm{SCr} \\
\text { level used to define } \\
\text { nephropathy }\end{array}$ & $\begin{array}{c}\text { Rate of } \\
\text { nephropathy, \%† }\end{array}$ & $\begin{array}{l}\text { Odds ratio } \\
(95 \% \mathrm{Cl}) \neq\end{array}$ \\
\hline $\begin{array}{l}\text { Boccalandro } \\
\text { et } \mathrm{al}^{80}\end{array}$ & 179 & $\begin{array}{l}600 \mathrm{mg} \text { twice } \\
\text { daily for } 48 \mathrm{~h}\end{array}$ & $\begin{array}{l}\text { Coronary } \\
\text { angiography } \\
\text { with or without } \\
\text { angioplasty }\end{array}$ & $159(53)$ & $\geq 44 \mu \mathrm{mol} / \mathrm{L}$ & $\begin{array}{l}\text { NAC: } 13 \\
\text { Placebo: } 12\end{array}$ & $1.14(0.43-2.98)$ \\
\hline Durham et $\mathrm{al}^{89}$ & 79 & $\begin{array}{l}1200 \mathrm{mg} 1 \mathrm{~h} \\
\text { before and } 3 \mathrm{~h} \\
\text { after the } \\
\text { procedure }\end{array}$ & $\begin{array}{l}\text { Coronary } \\
\text { angiography }\end{array}$ & $194(35)$ & $\geq 44 \mu \mathrm{mol} / \mathrm{L}$ & $\begin{array}{l}\text { NAC: } 26 \\
\text { Placebo: } 22\end{array}$ & $1.27(0.40-4.03)$ \\
\hline Briguori et $\mathrm{al}^{11}$ & 183 & $\begin{array}{l}600 \mathrm{mg} \text { twice } \\
\text { daily for } 48 \mathrm{~h}\end{array}$ & $\begin{array}{l}\text { Coronary or } \\
\text { peripheral } \\
\text { angiography } \\
\text { with or without } \\
\text { angioplasty }\end{array}$ & 133 (35) & $\geq 0.25 \%$ & $\begin{array}{l}\text { NAC: } 7 \\
\text { Placebo: } 11\end{array}$ & $0.95(0.61-1.48)$ \\
\hline $\begin{array}{l}\text { Allaqaband } \\
\text { et } \mathrm{al}^{64} \S\end{array}$ & 123 & $\begin{array}{l}600 \mathrm{mg} \text { twice } \\
\text { daily for } 48 \mathrm{~h}\end{array}$ & $\begin{array}{l}\text { Coronary } \\
\text { angiography } \\
\text { with or without } \\
\text { angioplasty }\end{array}$ & $177(53)$ & $\geq 44 \mu \mathrm{mol} / \mathrm{L}$ & $\begin{array}{l}\text { NAC: } 18 \\
\text { Placebo: } 15\end{array}$ & $1.23(0.34-4.51)$ \\
\hline $\begin{array}{l}\text { Goldenberg } \\
\text { et } \mathrm{al}^{86}\end{array}$ & 80 & $\begin{array}{l}600 \mathrm{mg} 3 \text { times } \\
\text { daily for } 48 \mathrm{~h}\end{array}$ & $\begin{array}{l}\text { Coronary } \\
\text { angiography } \\
\text { with or without } \\
\text { angioplasty }\end{array}$ & $177(34)$ & $\geq 44 \mu \mathrm{mol} / \mathrm{L}$ & $\begin{array}{l}\text { NAC: } 10 \\
\text { Placebo: } 8\end{array}$ & $1.30(0.27-6.21)$ \\
\hline
\end{tabular}

Note: Note: $\mathrm{SCr}=$ serum creatinine, $\mathrm{SD}=$ standard deviation, $\mathrm{Cl}=$ confidence interval.

*All patients received 24-hour saline hydration protocol.

†Difference was not statistically significant.

fOdds ratios are for NAC $v$. placebo with end point of contrast-medium nephropathy.

§One group of patients was randomly assigned to receive fenoldopam plus hydration.

『 Beneficial effect was observed only in patients with baseline SCr level of $221 \mu \mathrm{mol} / \mathrm{L}$ or greater. 
units with more severe renal dysfunction), the use of hemofiltration has been shown to improve short- and longterm outcomes.

Future studies should address the issue of preventing nephropathy in patients undergoing diagnostic or therapeutic procedures that require the use of contrast media who have not received, or who are unable to receive, appropriate hydration before the procedure. In addition, with

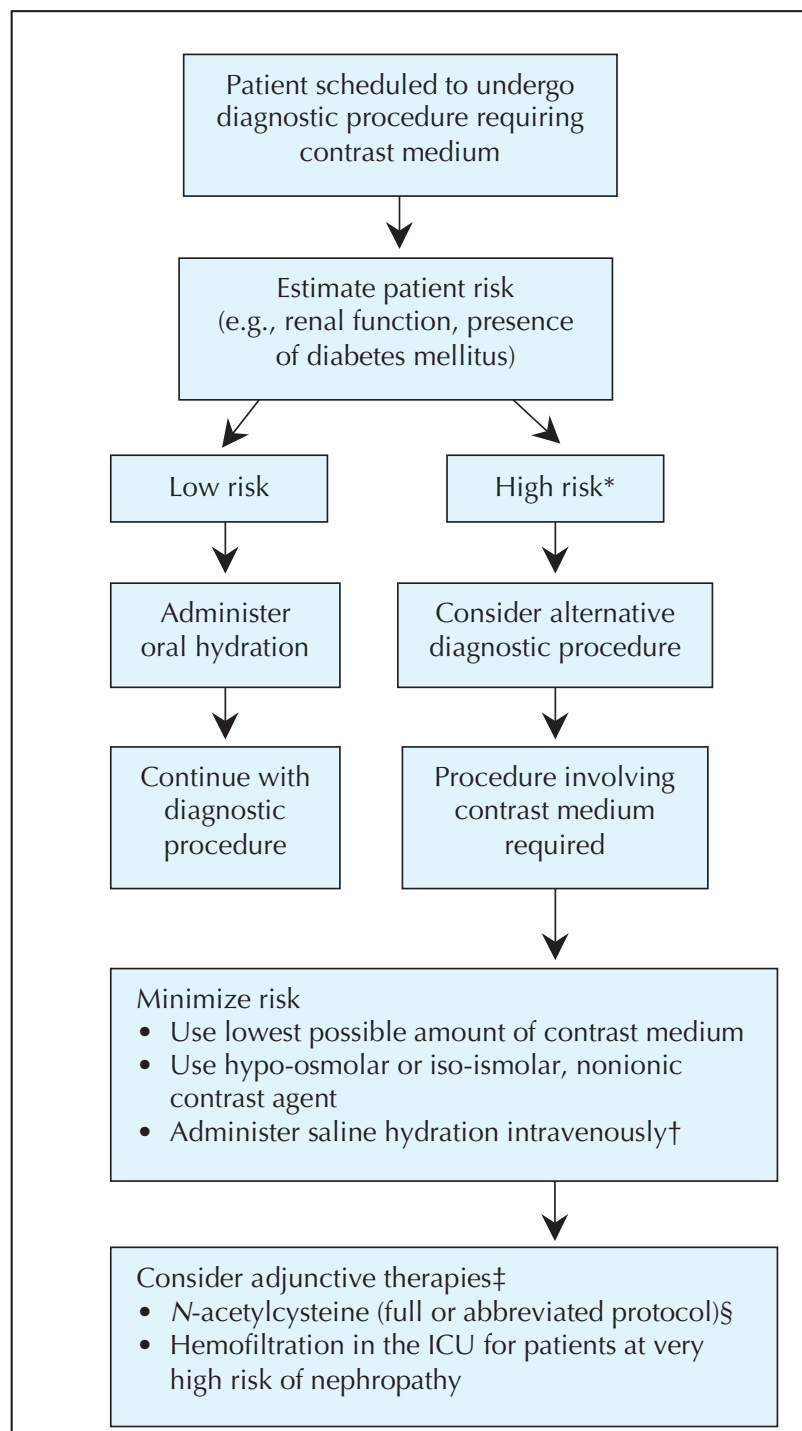

Fig. 1: Suggested management of patients scheduled to undergo diagnostic procedures involving use of a contrast medium. *Major risk factors are listed in Table 1. †A standard hydration protocol should include $45 \%$ saline administered intravenously at $1 \mathrm{~mL} / \mathrm{kg}$ hourly, 12 hours before and after exposure to the contrast medium. 抽arge prospective studies are required to validate the efficacy of these therapies in specific subgroups of high-risk patients. §An abbreviated protocol with $\mathrm{N}$-acetylcysteine may be required if full hydration is not feasible owing to severe unstable congestive heart failure or the need for an emergency procedure. the conflicting results observed in $N$-acetylcysteine trials, an appropriately powered multicentre randomized clinical study should be designed to evaluate the drug's efficacy in preventing contrast-medium nephropathy.

This article has been peer reviewed.

From the Heart Institute, Sheba Medical Center, Tel Hashomer, Israel (both authors) Competing interests: None declared.

Contributors: Both authors contributed to the conception, design and acquisition of data, the analysis and interpretation of data, and the drafting of the article. Both approved the final version to be published.

Acknowledgements: We thank Vivienne York for her editorial assistance.

\section{References}

1. Rich $M W$, Crecelius CA. Incidence, risk factors and clinical course of acute renal insufficiency after cardiac catheterization in patients 70 years of age or older: a prospective study. Arch Intern Med 1990;150:1237-42.

2. Cox CD, Tsikouris JP. Preventing contrast nephropathy: what is the best strategy? A review of the literature. 7 Clin Pharmacol 2004;44:327-37.

3. Brezis M, Epstein F.H. A closer look at radiocontrast-induced nephropathy. NEngl 7 Med 1989;320:179-81.

4. McCullough PA, Wolyn R, Rocher LL, Levin RN, O’Neill WW. Acute renal failure after coronary intervention: incidence, risk factors, and relationship to mortality. Am 7 Med 1997;103:368-75.

5. Rihal CS, Textor SC, Grill DE, Berger PB, Ting HH, Best PJ, et al. Incidence and prognostic importance of acute renal failure after percutaneous coronary intervention. Circulation 2002;105: 2259-64.

6. Barrett, BJ, Parfrey, PS. Prevention of nephrotoxicity induced by radiocontrast Agents. N Engl 7 Med 1994;331:1449-50.

7. Solomon R, Werner C, Mann D, D'Elia J, Silva P. Effects of saline, mannitol, and furosemide on acute decreases in renal function induced by radiocontrast agents. N Engl 7 Med 1994;331:1416-20.

8. Tepel M, van Der Giet M, Schwarzfeld C, Laufer U, Liermann D, Zidek W. Prevention of radiographic-contrast-agent-induced reductions in renal function by acetylcysteine. N Engl 7 Med 2000;343:180-4.

9. Shyu KJ, Cheng JJ, Kuan P. Acetylcysteine protects against acute renal damage in patients with abnormal renal function undergoing a coronary procedure. 7 Am Coll Cardiol 2002;40:1383-8.

10. Diaz-Sandoval LJ, Kosowsky BD, Losordo DW. Acetylcysteine to prevent angiography-related renal tissue injury (the APART trial). Am 7 Cardiol 2002, 89:356-8.

11. Briguori C, Manganelli F, Scarpato P Elia PP, Golia B, Riviezzo G et al. Acetylcysteine and contrast agent-associated nephrotoxicity. 7 Am Coll Cardiol 2002;40:298-03.

12. Berns AS. Nephrotoxicity of contrast media. Kidney Int 1989;36:730-40.

13. Moore RD, Steinberg EP, Powe NR, Brinker JA, Fishman EK, Graziano S et al. Nephrotoxicity of high osmolality versus low-osmolality contrast media: randomized clinical trial. Radiology 1992;182:649-55.

14. Morcos SK. Prevention of contrast media nephrotoxicity - the story so far. Clin Radiol 2004;59:381-9.

15. Cochran ST, Wong WS, Roe DJ. Predicting angiography-induced acute renal function impairment: clinical risk model. A7R Am f Roentgenol 1983;141: 1027-33.

16. Schillinger $M$, Haumer $M$, Mlekusch W, Schlerka G, Ahmadi R, Minar E. Predicting renal failure after balloon angioplasty in high-risk patients. $\mathcal{F} \mathrm{En}$ dovasc Ther 2001;8:609-14.

17. Sabeti S, Schillinger M, Mlekusch W, Ahmadi R, Minar E. Reduction in renal function after renal arteriography and after renal artery angioplasty. Eur 7 Vasc Endovasc Surg 2002;24:156-60.

18. Lufft V, Hoogestraat-Lufft L, Fels LM, Egbeyong-Baiyee D, Olbricht CJ Galanski M. Angiography for renal artery stenosis: no additional impairment of renal function by angioplasty. Eur Radiol 2002;12:804-9.

19. Caldicott WJH, Hollenberg NK, Abrams HL. Characteristics of response of renal vascular bed to contrast media. Evidence of vasoconstriction induced by renin-angiotensin system. Invest Radiol 1970;5:539-47.

20. Katzberg RW, Morris TW, Bururgener FA Kamm DE, Fischer HW. Renal renin and hemodynamic responses to selective renal artery catheterization and angiography. Invest Radiol 1977;12:381-8.

21. Heyman SN, Brezis M, Reubinoff CA, Greenfeld Z, Lechene C, Epstein FH et al. Acute renal failure with selective medullary injury in the rat. 7 Clin Invest 1988;82:401-12.

22. Heyman SN, Brezis M, Epstein FH Spokes K, Silva P, Rosen S. Early renal 
medullary hypoxic injury from radiocontrast media-induced acute renal failure. Kidney Int 1991;40:632-42.

23. Heyman SN, Rosen S, Brezis M. Radiocontrastnephropathy: a paradigm for the synergism between toxic and hypoxic insults in the kidney. Exp Nephrol $1994: 2: 153-7$.

24. Russo D, Minutolo R, Cianciaruso B, Memoli B, Conte G, De Nicola L. Early effects of contrast media on renal hemodynamics and tubular function in chronic renal failure. 7 Am Soc Nephrol 1995;6:1451-8.

25. Bakris GL, Lass NA, Glock D. Renal hemodynamics in radiocontrast medium-induced renal dysfunction: a role for dopamine-1 receptors. Kidney Int 1999;56:206-10.

26. Arend LJ, Bakris GL, Burnett JC Jr, Megerian C, Spielman WS. Role for intrarenal adenosine in the renal hemodynamic response to contrast media. $\mathcal{F}$ Lab Clin Med 1987;110:406-11.

27. Nygren A, Ulfendahl HR. Effects of high- and low-osmolar contrast media on renal plasma flow and glomerular filtration rate in euvolaemic and dehydrated rats. A comparison between ioxithalamate, iopamidol, iohexol and ioxaglate. Acta Radiol 1989;30:383-9.

28. Liss P, Nygren A, Olsson U, Ulfendahl HR, Erikson U. Effects of contrast media and mannitol on renal renal medullary blood flow and aggregation in the rat kidney. Kidney Int 1996;49:1268-75

29. Moreau JF, Droz D, Noel LE, Leibowitch J, Jungers P, Michel JR. Tubular nephrotoxicity of water-soluble iodinated contrast media. Invest Radiol 1980;15:S54-60.

30. Ueda J, Nygren A, Hansell P, Ulfendahl HR. Effect of intravenous contrast media on proximal and distal tubular hydrostatic pressure in the rat kidney. Acta Radiologica 1993;34:83-7.

31. Battenfeld R, Khater A el-R, Drommer W, Guenzel P, Kaup FJ. Ioxaglate-induced light and electron microscopic alterations in the renal proximal tubular epithelium of rats. Invest Radiol 1991;26:35-9.

32. Katholi RE, Woods WT Jr, Taylor GJ, Deitrick CL, Womack KA, Katholi $\mathrm{CR}$ et al. Oxygen free radicals and contrast nephropathy. Am 7 Kidney Dis 1998;32:64-71.

33. Hizoh I, Haller C. Radiocontrast-induced renal tubular cell apoptosis: hypertonic versus oxidative stress. Invest Radiol 2002;37:428-34.

34. Talner LB, Rushmer HN, Coel MN. The effect of renal artery injection of contrast material on urinary enzyme excretion. Invest Radiol 1972;7:311-22.

35. Reed JR, Williams RH, Luke RG. The renal hemodynamic response to diatrizoate in normal and diabetic rats. Invest Radiol 1983;18:536-40.

36. Hizoh I, Strater J, Schick CS, Kubler W, Haller C. Radiocontrast-induced DNA fragmentation of renal tubular cells in vitro: role of hypertonicity. Nephrol Dial Transplant 1998;13:911-8.

37. Liss P, Nygren A, Erikson U, Ulfendahl HR. Injection of low and iso-osmolar contrast media decreases oxygen tension in the renal medulla. Kidney Int 1998;53:698-702.

38. Lancelot E, Idee J-P, Lacledere C, Santus R, Corot C. Effects of two dimeric iodinated contrast media on renal medullary blood perfusion and oxygenation in dogs. Invest Radiol 2002;37:368-75.

39. Barrett BJ, Carlisle EJ. Meta-analysis of the relative nephrotoxicity of highand low-osmolality iodinated contrast media. Radiology 1993;188:171-8.

40. Aspelin P, Aubry P, Fransson SG, Strasser R, Willenbrock R, Berg KJ, the NEPHRIC Study Investigators. Nephrotoxic effects in high-risk patients undergoing angiography. NEngl 7 Med 2003; 348:491-9.

41. Iakovou I, Dangas G, Mehran R, Lansky AJ, Ashby DT, Fahy M, et al. Impact of gender on the incidence and outcome of contrast-induced nephropathy after percutaneous coronary intervention. F Invasive Cardiol 2003;15:18-22

42. Gruberg L, Mehran R, Dangas G, Mintz GS, Waksman R, Kent KM, et al. Acute renal failure requiring hemodialysis after percutaneous coronary intervention: in-hospital and one-year outcomes. Catheter Cardiovasc Interv 2001;52:409-16.

43. Parfrey PS, Griffiths SM, Barrett BJ, Paul MD, Genge M, Withers J, et al. Contrast material-induced renal failure in patients with diabetes mellitus, renal insufficiency, or both. A prospective controlled study. N Engl 7 Med 1989; 320:143-9

44. Gussenhoven MJ, Ravensbergen J, van Bockel JH, Feuth JD, Aarts JC. Renal dysfunction after angiography: a risk factor analysis in patients with peripheral vascular disease. 7 Cardiovasc Surg (Torino) 1991;32:81-6.

45. Louis BM, Hoch BS, Hernandez C, Namboodiri N, Neiderman G, Nissenbaum A, et al. Protection from the nephrotoxicity of contrast dye. Ren Fail 1996;18:639-46.

46. Cantley LG, Spokes K, Clark B, McMahon EG, Carter J, Epstein FH. Role of endothelin and prostaglandins in radiocontrast induced renal artery constriction. Kidney Int 1993;44:1217-23.

47. Freeman RV, O'Donnell M, Share D, Meengs WL, Kline-Rogers E, Clark VL, et al, Blue Cross-Blue Shield of Michigan Cardiovascular Consortium (BMC2). Nephropathy requiring dialysis after percutaneous coronary intervention and the critical role of an adjusted contrast dose. Am 7 Cardiol 2002;90:1068-73

48. Cigarroa RG, Lange RA, Williams RH, Hillis LD. Dosing of contrast material to prevent contrast nephropathy in patients with renal disease. Am 7 Med 1989;86:649-52.
49. Rudnick MR, Goldfarb S, Wexler L, Ludbrook PA, Murphy MJ, Halpern EF, et al. Nephrotoxicity of ionic and nonionic contrast media in $1196 \mathrm{pa}-$ tients: a randomized trial. The Iohexol Cooperative Study. Kidney Int 1995;47:254-61.

50. Taliercio CP, Vlietstra RE, Ilstrup DM, Burnett JC, Menke KK, Stensrud SL, et al. A randomized comparison of the nephrotoxicity of iopamidol and diatrizoate in high risk patients undergoing cardiac angiography. $7 \mathrm{Am}$ Coll Cardiol 1991;17:384-90.

51. Schwab SJ, Hlatky MA, Pieper KS, Davidson CJ, Morris KG, Skelton TN, et al. Contrast nephrotoxicity: a randomized controlled trial of a nonionic and an ionic radiographic contrast agent. $N$ Engl 7 Med 1989;320:149-53.

52. Mehran R, Aymong ED, Nikolsky E, Lasic Z, Iakovou I, Fahy M, et al. A simple risk score for prediction of contrast-induced nephropathy after percutaneous coronary intervention: development and initial validation. $7 \mathrm{Am}$ Coll Cardiol 2004;44:1393-9.

53. Barrett BJ. Contrast nephrotoxicity. 7 Am Soc Nephrol 1994;5:125-37. 1989:320:179-81.

54. Levy EM, Viscoli CM, Horwitz RI. The effect of acute renal failure on mortality. A cohort analysis. FAMA 1996;275:1489-94.

55. Stevens MA, McCullough PA, Tobin KJ, Speck JP, Westveer DC, GuidoAllen DA, et al. A prospective randomized trial of prevention measures in patients at high risk for contrast nephropathy: results of the P.R.I.N.C.E. Study. Prevention of Radiocontrast Induced Nephropathy Clinical Evaluation. $7 \mathrm{Am}$ Coll Cardiol 1999;33:403-11.

56. Taylor AJ, Hotchkiss D, Morse RW, McCabe J. PREPARED: Preparation for Angiography in Renal Dysfunction: a randomized trial of inpatient vs outpatient hydration protocols for cardiac catheterization in mild-to-moderate renal dysfunction. Chest 1998;114:1570-4.

57. Mueller C, Buerkle G, Buettner HJ, Petersen J, Perruchoud AP, Eriksson U, et al. Prevention of contrast media-associated nephropathy: randomized comparison of 2 hydration regimens in 1620 patients undergoing coronary angioplasty. Arch Intern Med 2002;162:329-36.

58. Merten GJ, Burgess WP, Gray LV, Holleman JH, Roush TS, Kowalchuk GJ, et al. Prevention of contrast-induced nephropathy with sodium bicarbonate: a randomized controlled trial. 7AMA 2004;291:2328-34.

59. Annapoorna K, Sharma S. Managing the high risk patient: experience with fenoldopam, a selective dopamine receptor agonist, in prevention of radiocontrast nephropathy during percutaneous coronary intervention. Rev Cardiovasc Med 2001;2(Suppl 1):S19-25.

60. Kini AA, Mitre CA, Kamran M, Kim M, Duffy ME, Marmur JD, et al Changing trends in incidence and predictors of radiographic contrast nephropathy after percutaneous coronary intervention with use of fenoldopam. Am 7 Cardiol 2002;89:999-1002.

61. Madyoon H, Croushore L, Weaver D, Mathur V. Use of fenoldopam to prevent radiocontrast nephropathy in high-risk patients. Catheter Cardiovasc Interv 2001;53:341-5.

62. Tumlin JA, Wang A, Murray PT, Mathur VS. Fenoldopam mesylate blocks reductions in renal plasma flow after radiocontrast dye infusion: a pilot trial in the prevention of contrast nephropathy. Am Heart 7 2002;143:894-903.

63. Stone G, McCullough P, Tumlin J, Lepor NE, Madyoon H, Murray, et al. Fenoldopam mesylate for the prevention of contrast-induced nephropathy: a randomized controlled trial. 7AMA 2003;290:2284-91.

64. Allaqaband S, Tumuluri R, Malik AM, Gupta A, Volkert P, Shalev Y, et al. Prospective randomized study of $N$-acetylcysteine, fenoldopam, and saline for prevention of radiocontrast-induced nephropathy. Catheter Cardiovasc Interv 2002;57:279-83.

65. Briguori C, Colombo A, Airoldi F, Violante A, Castelli A, Balestrieri P, et al. $\mathrm{N}$-Acetylcysteine versus fenoldopam mesylate to prevent contrast agentassociated nephrotoxicity. 7 Am Coll Cardiol 2004:18;44:762-5.

66. Hans SS, Hans BA, Dhillon R, Dmuchowski C, Glover J. Effect of dopamine on renal function after arteriography in patients with preexisting renal insufficiency. Am Surg 1998;34:1682-8.

67. Kapoor A, Sinha N, Sharma RK, Shrivastava S, Radhakrishnan S, Goel PK, et al. Use of dopamine in prevention of contrast induced acute renal failure: a randomized study. Int 7 Cardiol 1996;53:233-6

68. Gare M, Haviv Y, Ben-Yehuda A, Bdolah-Abram T, Fuchs S, Gat O, et al. The renal effects of low-dose dopamine in high risk patients undergoing coronary angiography. 7 Am Coll Cardiol 1999;34:1682-8.

69. Abizaid AS, Clark CE, Mintz GS, Dosa S, Popma JJ, Pichard AD, et al. Effects of dopamine and aminophylline on contrast-induced acute renal failure after coronary angioplasty in patients with preexisting renal insufficiency. $\mathrm{Am}$ 7 Cardiol 1999;83:260-3, A5.

70. Juste RN, Moran L, Hooper J, Soni N. Dopamine clearance in critically ill patients. Intensive Care Med 1998:1217-20

71. Kapoor A, Kumar S, Gulati S, Gambhir S, Sethi RS, Sinha N. The role of theophylline in contrast-induced nephropathy: a case-control study. Nephrol Dial Transplant 2002;17:1936-41.

72. Huber W, Ilgmann K, Page M. Effect of theophylline on contrast materialinduced nephropathy in patients with chronic renal insufficiency: controlled, randomized, double-blinded study. Radiology 2002;223:772-9.

73. Erley CM, Duda SH, Rehfuss D, Scholtes B, Bock J, Muller C, et al. Preven- 
tion of radiocontrast-media-induced nephropathy in patients with pre-existing renal insufficiency by hydration in combination with the adenosine antagonist theophylline. Nephrol Dial Transplant 1999;14:1146-9.

74. Bakris $G$, Burnett $J$. A role for calcium in radiocontrast induced reductions in renal hemodynamics. Kidney Int 1985;27:465-8.

75. Spangberg-Viklund B, Berglund J, Nikonoff T, Nyberg P, Skau T, Larsson R. Does prophylactic treatment with felodopine, a calcium antagonist, prevent low-osmolar contrast induced renal dysfunction in hydrated diabetic and nondiabetic patients with normal or moderately reduced renal function? Scand 7 Urol Nephrol 1996;30:63-8.

76. Neumayer HH, Junge W, Kufner A, Wening A. Prevention of radiocontrastmedia-induced nephrotoxicity by the calcium channel blocker nitrendipine: a prospective randomised clinical trial. Nephrol Dial Transplant 1989;4:1030-6.

77. Wang A, Holcslaw T, Bashore TM, Freed MI, Miller D, Rudnick MR, et al Exacerbation of radiocontrast nephrotoxicity by endothelin receptor antagonism. Kidney Int 2000;57:1675-80.

78. Koch JA, Plum J, Grabensee B, Modder U. Prostaglandin E1: A new agent for the prevention of renal dysfunction in high risk patients caused by radiocontrast media? Nephrol Dial Transplant 2000;15:43-9.

79. Drager LF, Andrade L, Barros de Toledo JF, Laurindo FR, Machado Cesar LA, Seguro AC. Renal effects of $\mathrm{N}$-acetylcysteine in patients at risk for contrast nephropathy: decrease in oxidant stress-mediated renal tubular injury. Nephrol Dial Transplant 2004;19:1803-7.

80. Boccalandro F, Amhad M, Smalling RW, Sdringola S. Oral acetylcysteine does not protect renal function from moderate to high doses of intravenous radiographic contrast. Catheter Cardiovasc Interv 2003;58:336-41.

81. Miner SE, Dzavik V, Nguyen-Ho P, Richardson R, Mitchell J, Atchison D, et al. $N$-Acetylcysteine reduces contrast-associated nephropathy but not clinical events during long-term follow-up. Am Heart 7 2004;148:690-5.

82. Birck R, Krzossok S, Markowetz F, Schnulle P, van der Woude FJ, Braun C. Acetylcysteine for prevention of contrast nephropathy: meta-analysis. Lancet 2003;362:598-603.

83. Kshirsagar AV, Poole C, Mottl A, Franceschini N, Tudor G, Agrawal M, et al. $\mathrm{N}$-Acetylcysteine for the prevention of radiocontrast induced nephropathy: meta-analysis of prospective controlled trials. 7 Am Soc Nephrol 2004;15:761-9.

84. Pannu N, Manns B, Lee H, Tonelli M. Systematic review of the impact of $N$-acetylcysteine on contrast nephropathy. Kidney Int 2004;65:1366-74.

85. Fishbane S, Durham JH, Marzo K, Rudnick M. N-Acetylcysteine in the prevention of radiocontrast-induced nephropathy. 7 Am Soc Nephrol 2004;15:251-60.

86. Goldenberg I, Shechter M, Matetzky S, Jonas M, Adam M, Pres H, et al. Oral acetylcysteine as an adjunct to saline hydration for the prevention of contrastinduced nephropathy following coronary angiography. A randomized controlled trial and review of the current literature. Eur Heart 7 2004;25:212-8.

87. Kay J, Chow WH, Chan TM, Lo SK, Kwok OH, Yip A, et al. Acetylcysteine for prevention of acute deterioration of renal function following elective coronary angiography and intervention: a randomized controlled trial. $\mathcal{F} A M A$ 2003;289:553-8

88. MacNeill BD, Harding SA, Bazari H, Patton KK, Colon-Hernadez P, DeJoseph D, et al. Prophylaxis of contrast-induced nephropathy in patients undergoing coronary angiography. Catheter Cardiovasc Interv 2003;60:458-61.

89. Durham JD, Caputo C, Dokko J, Zaharakis T, Pahlavan M, Keltz J, et al. A randomized controlled trial of $\mathrm{N}$-acetylcysteine to prevent contrast nephropathy in cardiac angiography. Kidney Int 2002;62:2202-7.

90. Ochoa A, Pellizzon G, Addala S, Grines C, Isayenko Y, Boura J et al. Abbreviated dosing of $\mathrm{N}$-acetylcysteine prevents contrast-induced nephropathy after elective and urgent coronary angiography and intervention. 7 Interv Cardiol 2004:17:159-65.

91. Baker CS, Wragg A, Kumar S, De Palma R, Baker LR, Knight CJ. A rapid protocol for the prevention of contrast-induced renal dysfunction: the RAPPID study. 7 Am Coll Cardiol 2003;41:2114-8.

92. Briguori C, Colombo A, Violante A, Balestrieri P, Manganelli F, Paolo Elia $\mathrm{P}$, et al. Standard vs double dose of $N$-acetylcysteine to prevent contrast agent associated nephrotoxicity. Eur Heart 7 2004;25:206-11.

93. Spargias K, Alexopoulos E, Kyrzopoulos S, Iacovis P, Greenwood DC Manginas A, et al. Ascorbic acid prevents contrast-mediated nephropathy in patients with renal dysfunction undergoing coronary angiography or intervention. Circulation 2004;110:2837-42.

94. Vogt B, Ferrari P, Schonholzer C, Marti HP, Mohaupt M, Wiederkehr M, et al. Prophylactic hemodialysis after radiocontrast media in patients with renal insufficiency is potentially harmful. Am 7 Med 2001;111:692-8.

95. Marenzi G, Marana I, Lauri G, Assanelli E, Grazi M, Campodonico J, et al. The prevention of radiocontrast-agent-induced nephropathy by hemofiltration. N Engl f Med 2003;349:1333-40.

Correspondence to: Dr. Ilan Goldenberg, Heart Institute, Sheba Medical Center, Tel Hashomer 52621, Israel; fax +9723534 3888; ilan.goldenberg@heart.rochester.edu orvivienne.york@sheba.health.gov.il

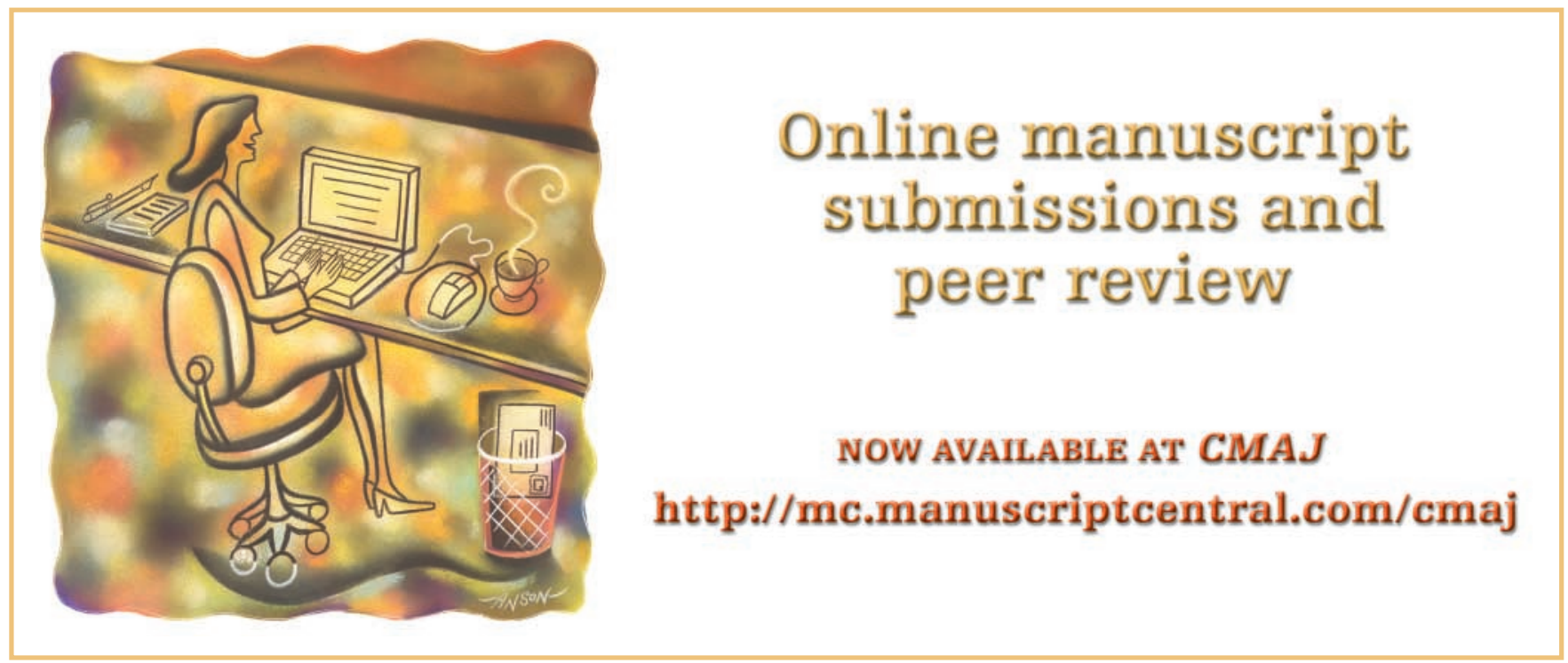

